\title{
USERS' SATISFACTION WITH DOMESTIC WATER SUPPLY IN NEPAL - A STUDY IN LEKHNATH SMALL TOWN WATER SUPPLY AND SANITATION PROJECT
}

\author{
Narayan Timilsena \\ Department of Civil and Geomatics Engineering, Pashchimanchal Campus, Pokhara \\ E-mail:narayant@wrc.edu.np
}

\begin{abstract}
Water Supply and Sanitation has been a priority of Government of Nepal. Various types of urban and rural water supply and sanitation projects are now being implemented within the Government, private and NGO sectors. The normal practice of measurement of satisfaction by service providers is to measure consumers' satisfaction on past performance. The survey design could vary from survey questions to unstructured interviews and everything in between using comparative and non-comparative scales. In comparative scaling, the respondents are asked to compare one product against the other while non-comparative scaling is used to evaluate a single product. In this study, Likert Scales is used in this study for measurement of customer satisfaction on water supply. The higher level of satisfaction with water supply is expected to be positively related to several factors such as satisfaction with water quality, and other parameters such as hours and timings of water supply, tap pressure, quantity of water supplied, responsiveness and communication of management and water tariff. The respondents' level of satisfaction indicates that about 41 percent of respondents were neutral, they were neither satisfied nor dissatisfied with water services, while about 36 percent of respondents were satisfied with water services. The satisfaction scale of overall satisfaction with water services was 3.29 while 1.0 indicates strongly not satisfied while 5.0 indicate strongly satisfied. The various aspects that influence satisfaction among users which include hours and timings of water supply, tap pressure, quantity of water supplied, responsiveness and communication of management and water tariff as well as redresses of customer complaints have been examined. This study focused on the users' satisfaction of Lekhnath small town water supply and sanitation project and the study was undertaken to analyze the current users' satisfaction of the Lekhnath small town water supply and sanitation project. The result showed that the satisfaction level of users' is above neutral but these were not in satisfying level. The characteristics/aspects of the service that contributed to users' satisfaction including hours and timing, pressure, quantity and quality of water while there was slightly less satisfaction with regard to complaints about water supply.
\end{abstract}

\section{Keywords}

Users' Satisfaction, Likert Scale, Users' committee 
Nepal Engineers' Association, Gandaki

\section{Introduction}

Study of customer satisfaction is of prime importance in encouraging performance improvement of any service provider. This is true even in the case of government-owned organizations such as those which provide essential services such as water supply. Water is basic need and human right of people. People need water for various domestic purposes like drinking, cooking, sanitation, and irrigation. Besides domestic use, people also need water for other diversified livelihood including livestock, gardening, cropping, food processing, aquaculture and fisheries (Soussan 2003; Kopper et al. 2006). In rural and periurban areas of developing countries, where main occupation is agriculture depends upon water to sustain livelihood (Soussan 2003; Renwick et al. 2007).

Water is also an essential resource for survival and to secure good health. But people around the world are facing the problems of water scarcity. This scarcity of water forced the people to use unsafe water for the drinking and other domestic purposes (WHO, 2009). Water supplies and sanitation were first highlighted on the development agenda about 35 years ago. This was a result of the 1977 United Nations Conference in Mar del Plata, Argentina that recommended proclaiming the 1980s to be the International Drinking Water Supply and Sanitation Decade with the goal of "providing every person with access to water of safe quality and adequate quantity, along with basic sanitary facilities, by 1990" (World Water Assessment Programme, 2003). International water policies and management practices have generally considered water to be a free and renewable resource. Governments in developing countries have often subsidized water supplies, typically in an attempt to achieve social and health benefits for low-income households that comprise a large majority of the rural population (Lammerink, 1998; Whittington et al. 1998). Furthermore, developing countries have made huge investments in their rural water supplies under the presumption that local communities will be involved in their maintenance and operation.

Water Supply and Sanitation has been a priority of Government of Nepal. Various types of urban and rural water supply and sanitation projects are now being implemented within the Government, private and NGO sectors. However, faster urbanization has put pressure on these sectors to diversify their activities and implement multiple projects. To cater to the increasing demands of drinking water and sanitation facilities for faster growing towns and market centers, Government of Nepal has initiated a community supported water supply and sanitation project with financial assistance from the Asian Development Bank (ADB). This project is called the "Small Towns Water Supply and Sanitation Project" (STWSSP). Consumer satisfaction is closely linked to acceptance and pReferences. Satisfaction is the fulfillment and gratification of the need for a stated good or service. The level of satisfaction is therefore determined by the perceived performance of a company or utility, which is an evaluation of the delivered good or service viewed in the light of the consumers' needs. Due to varying geographical locations and socioeconomic conditions among rural villages and rural market centers, core operation and maintenance problems for drinking water sustainability are immensely different. Weak 
institutional capacity is the prime obstacle in the provision of drinking water in the rural villages while technicalities such as insufficient water quality and inconvenient water tariff are the major issues in the rural market centers. Moreover, levels of user satisfaction influence the operation and maintenance of both types of systems. Many scholars claim that water supply projects will be sustainable when consumers are willing to pay user charges that are sufficient to cover all costs in excess of grants. This study considers user-satisfaction parameters such as hours and timing of provision, quantity, tap pressure, quality of water, responsiveness and communication of management and the overall influence of satisfaction on users' willingness to pay.

The operation and maintenance costs of DWS projects in rural areas of Nepal should be covered by the community itself while the investment cost for such projects should be financed by the government or donor agencies. Communities may also contribute to project investment by providing labor, land, and local materials. A sustainable water future depends on appropriate prices and the necessary resources need to come from project consumers (World Bank Water Demand Research Team, 1993; Whittington, 1998). However, Whittington et al. (1990) discovered that rural customers in Nigeria do not want to pay for water in advance or commit themselves to a fixed monthly payment due to their mistrust of public providers. Some scholars have focused on community-water education and the creation of organizational capacity to ensure project sustain-ability (Baker et al. 2006). The literature shows that water-user committees play a vital role in the sustainability of rural water schemes and that the enhancement of facilitation skills, the clarification of responsibilities, the improvement of transparency in decision making, and the augmentation of credibility are essential for making a committee trustworthy (Lopez-Gunn and Cortina, 2006).

The focal issue in the water supply \& sanitation sector today is how scheme can be made to last and how the sector's development can be made sustainable.

\section{Methodology}

\subsection{Description of the Study Area}

Former Lekhnath Municipality is one of the most densely populated areas in the mid-hills of Nepal. It is situated $200 \mathrm{kms}$ west of Kathmandu and $6.25 \mathrm{kms}$ east from Pokhara city center on the Prithivi Highway connecting Kathmandu with Pokhara. As per the District Water Supply Office (DWSO), there are 17 gravity water supply schemes in the municipality supplying water through 294 tap stands. As per Social Works Group (SWOG), the final beneficiary project households in year 2015 are 9357. These project households and population are planned to be served by two Lapsi Danda and Danda Ko Nak water supply systems and two existing Arghaun and Shishuwa-Khudi water supply systems. The Lapsi Danda system has cover 2302 households of ward nos. 26 and 27. The Danda Ko Nak system has cover 5628 households of ward nos. 29, 30 \& 31. Similarly, the existing Arghaun system has cover 480 households of ward nos. 26 and 27 and the existing ShishuwaKhudi system will cover 947 households of ward nos. 29, 30 \& 31 in year 2018.

\subsection{Empirical Methods}

The normal practice of measurement of satisfaction by service providers is to measure 
consumers' satisfaction on past performance. Vloerbergh et al., (2007) explained that the survey design could vary from survey questions to unstructured interviews and everything in between using comparative and noncomparative scales. In comparative scaling, the respondents are asked to compare one product against the other while non-comparative scaling is used to evaluate a single product. In this study, Likert Scales is used in this study for measurement of customer satisfaction on water supply.

\subsubsection{Sampling}

The number of surveyed households was based on the annual project report prepared by the water user committee. A sample size of 396 households was selected from a total of 5628 (Lekhnath Small Town Water Supply \& Sanitation Project office, 2016) benefited households of Dandako Nak system (Largest distribution system) of the project. The sampling Methodology assumed at $95 \%$ confidence level. The sample size was computed from the following formula (Arkin and Colton 1963).

$\mathrm{n}=\frac{\mathrm{NZ}^{2} * \mathrm{p} *(1-\mathrm{p})}{\mathrm{Nd}^{2}+\mathrm{Z}^{2} * \mathrm{p}(1-\mathrm{p})}$

Where,

$\mathrm{n}=$ Sample size

$\mathrm{N}=$ Total number of households

$\mathrm{Z}=$ Confidence level (at 95\% level, $\mathrm{Z}=1.96$ )

$\mathrm{p}=$ Estimated population proportion (0.5)

$\mathrm{d}=$ error limit of $5 \%(0.05)$

This gives the sample size as 360, and 400 sample questionnaires were distributed for primary data collection.

\section{Data Analysis}

\subsection{Methods of Primary and Secondary Data} Collection

The primary data have been collected with the help of survey through the structured questionnaire among the users regarding the level of satisfaction and its determinants. For the collection of users' opinion, 400 printed questionnaires were distributed among the users. Out of the 400 distributed questionnaires, only 396 questionnaires were collected which almost took one and half month.

The secondary data of required dependent and independent variables were collected from official websites of Lekhnath small town water supply and sanitation project, annual reports, audit reports and relevant articles and publications.

\subsection{Level of Satisfaction}

This study intends to examine the level of satisfaction of users. The composite index approach is also a simple and straightforward format that is widely used in planning and evaluation studies such as the humandevelopment index and the rating index (Sullivan, 2002; Sullivan et al. 2003). Specifically, this satisfaction scale was developed on the basis of factor analysis to measure user satisfaction (Figure 3.1).

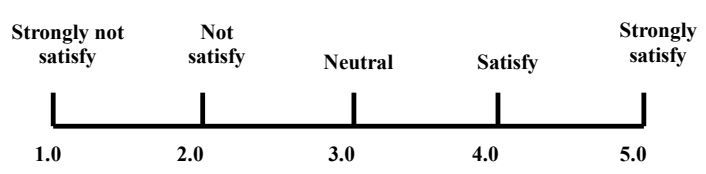

Figure 3.1: Satisfaction Scale

$$
A W I=\frac{f_{a}(1)+f_{b}(2)+f_{c}(3)+f_{d}(4)+f_{e}(5)}{N}
$$

Where,

AWI $=$ Average weighted index 
$\mathrm{fa}=$ Frequency of strongly not satisfy

$\mathrm{fb}=$ Frequency of not satisfy

$\mathrm{fc}_{\mathrm{c}}=$ Frequency of neutral

$\mathrm{fd}=$ Frequency of satisfy

$\mathrm{fe}=$ Frequency of strongly satisfy

$\mathrm{N}=$ Total no. of observation

\section{Results of the Study}

\subsection{Background Characteristics of the Respondents}

Table 4.1: Respondents' Background Characteristics

\begin{tabular}{llll}
\hline Characteristics & Percent (No.) & Characteristics & Percent (No.) \\
\hline Age & & Occupation & \\
$20-30$ & $12.63(50)$ & Agriculture & $25.75(102)$ \\
$30-40$ & $37.88(150)$ & Business & $21.46(85)$ \\
40 and above & $49.49(196)$ & Private job & $9.34(37)$ \\
Gender & & Service & $17.42(69)$ \\
Male & $64.40(255)$ & Student & $4.29(17)$ \\
Female & $35.60(141)$ & Housewife & $5.05(20)$ \\
Marital status & & Teacher & $3.53(14)$ \\
Married & $89.65(355)$ & Others & $13.13(52)$ \\
Unmarried & $10.35(41)$ & Family lived in house & \\
Education & & Less than 1 year & $11.36(45)$ \\
Illiterate & $9.85(39)$ & More than 1 years & $88.64(351)$ \\
Primary/Literate & $21.21(84)$ & Payment of water tariff & \\
Secondary & $39.14(155)$ & Monthly & $92.40(366)$ \\
University & $29.80(118)$ & Non monthly & $7.60(30)$ \\
\hline
\end{tabular}

(Source: Responses on survey questionnaire, 2018)

Out of the total respondents, it reveals that about 13 percent of the respondents were of the age between 20 to 30 years. About 38 percent were age of between 30 to 40 years and remaining about 49 percent of the respondents were above 40 years. Among the respondents above 64 percent of the respondents were men while 36 percent of the respondents were women, though there were variations in the proportion of men and women respondents
This section deals with the background characteristics of respondents such as age, gender, marital status, education, occupation etc. which also gets influenced in overall satisfaction with water services. The table 4.1 shows the background characteristics of the respondents. 
About 12 percent of respondents' family had lived less than 1 year in the house while 88 percent of respondents' family lived more than 1 year in the house. Regarding the socioeconomic status of the respondents, about 93 percent of the respondents were paying water tariff monthly while 7 percent of the respondents were not pay water tariff monthly.

\subsubsection{Social Characteristics}

Social characteristics of the respondents of the questionnaire survey conducted among the users of Lekhnath small town water supply and sanitation project have made in this section. The table presented below illustrates the social characteristics of the respondents based on their household size, income sources of family and types of house roof, sources being used before project and collection method of water from pipe line. Respondent's family background may also behaving effects on water use, demand, collection and overall satisfaction with water services in the households.

Table 4.2: Respondents' Social Characteristics

\begin{tabular}{llll}
\hline Characteristics & Percent (No.) & Characteristics & Percent (No.) \\
\hline Household member & & Income source of family & \\
Less than 5 & $64.39(255)$ & Agriculture & $27.78(110)$ \\
$5-10$ & $34.60(137)$ & Service & $21.72(86)$ \\
More than 10 & $1.01(4)$ & Business & $21.97(87)$ \\
Types of roof & & Private job & $10.86(43)$ \\
RCC & $69.19(274)$ & Others & $17.68(70)$ \\
CGI sheet roof & $22.47(89)$ & Collection of water from pipeline \\
Thatched roof & $4.04(16)$ & From tap & $51.52(204)$ \\
Others & $4.30(17)$ & From underground tank & $13.13(52)$ \\
& & Both & $35.35(140)$ \\
\hline
\end{tabular}

(Source: Responses on survey questionnaire, 2018)

The result shows that, more than 64 percent of household had less than 5 members, about 35 percent of household had family member between 5 to 10 and only 1 percent of the respondent's family had more than 10 members. About 28 percent of the respondents' family had agriculture as the main income source, more than 21 percent had service, more than 21 percent had business, more than 10 percent had private job as a source of income of respondents' family and about 18 percent of the respondents' family had other source of income to sustain their livelihood. Among the respondents' house roof more than 69 percent were RCC roof, similarly more than 22 percent of house roof were CGI sheet roof while about 4 percent house roof were thatched roof. About 53 percent of respondents' families collected water from tap only while about 13 percent were collected water from underground tap only and about 35 percent of respondents' families were collected water from both Methods. 


\subsection{Level of Satisfaction with Water Supply}

Users' satisfaction is closely linked to acceptance and pReferences. Satisfaction is the fulfillment and gratification of the need for a stated good or service. The level of satisfaction is therefore determined by the perceived performance of a company or utility, which is an evaluation of the delivered good or service viewed in the light of the consumers' needs. Most satisfaction measurement Methods currently used by water utilities compare people's satisfaction against past performance. The measures pose questions about past experiences, and opinions in the past, or at best current policies and practices of the water services. The table 4.3 summarizes the frequency of satisfaction in different parameters.

Table 4.3: Frequency/Percent of Users' Satisfaction

\begin{tabular}{|c|c|c|c|c|c|c|}
\hline \multirow[b]{2}{*}{ Determinants } & \multicolumn{6}{|c|}{ Satisfaction Points } \\
\hline & $\begin{array}{l}\text { Strongly } \\
\text { not satisfy }\end{array}$ & $\begin{array}{l}\text { Not } \\
\text { satisfy }\end{array}$ & Neutral & Satisfy & $\begin{array}{l}\text { Strongly } \\
\text { satisfy }\end{array}$ & Total \\
\hline \multirow[t]{2}{*}{ Hours \& timing } & 0.8 & 11.4 & 35.9 & 46.0 & 6.1 & 100 \\
\hline & (3) & $(45)$ & $(142)$ & $(182)$ & $(24)$ & (396) \\
\hline \multirow[t]{2}{*}{ Quantity } & 2.0 & 10.9 & 37.4 & 41.9 & 7.8 & 100 \\
\hline & $(8)$ & $(43)$ & $(148)$ & $(166)$ & $(31)$ & (396) \\
\hline \multirow[t]{2}{*}{ Tap pressure } & 2.5 & 10.6 & 40.4 & 44.4 & 2.0 & 100 \\
\hline & $(10)$ & $(42)$ & $(160)$ & $(176)$ & (8) & (396) \\
\hline \multirow[t]{2}{*}{ Quality } & 0.3 & 10.4 & 43.2 & 42.2 & 4.0 & 100 \\
\hline & $(1)$ & $(41)$ & $(171)$ & $(167)$ & $(16)$ & (396) \\
\hline Responsiveness & 2.5 & 12.6 & 44.2 & 37.1 & 3.5 & 100 \\
\hline \&communication & $(10)$ & $(50)$ & (175) & $(147)$ & $(14)$ & (396) \\
\hline \multirow[t]{2}{*}{ Water tariff } & 3.3 & 15.4 & 37.4 & 38.6 & 5.3 & 100 \\
\hline & (13) & $(61)$ & (148) & (153) & $(21)$ & (396) \\
\hline Overall water & 3.5 & 11.4 & 44.4 & 35.4 & 5.3 & 100 \\
\hline services & (14) & $(45)$ & $(176)$ & $(140)$ & $(21)$ & (396) \\
\hline
\end{tabular}

Source: Responses on survey questionnaire, 2018

The respondents were asked different statements representing the determinants of level of users' satisfaction. The statements were designed in five point likert scale indicating " 1 " as 'strongly not satisfied' to " 5 " as 'strongly satisfied' and shown in the table below. 
Nepal Engineers' Association, Gandaki

Table 4.4: Level of Users' Satisfaction

\begin{tabular}{lc}
\hline Categories of Satisfaction & Users' Satisfaction Level \\
\hline Satisfaction with hours \& timing & 3.45 \\
Satisfaction with quantity & 3.43 \\
Satisfaction with tap pressure & 3.33 \\
Satisfaction with quality of water & 3.29 \\
Satisfaction with responsiveness \& communication of management & 3.27 \\
Satisfaction with water tariff & 3.27 \\
Satisfaction with overall water services & 3.28 \\
\hline
\end{tabular}

Source: Responses on survey questionnaire, 2018

4.2.1 Satisfaction with Hours and Timing of Water Supply

Continuity in water supply is most essential for satisfaction of users. The timing and duration of water supply in Danda Ko Nak distribution system is shown in table 4.5 .

Table 4.5: Hours and Timing of Water Supply

\begin{tabular}{|l|l|l|l|}
\hline $\begin{array}{l}\text { Distribution } \\
\text { System }\end{array}$ & $\begin{array}{l}\text { Days of } \\
\text { Supply }\end{array}$ & Timing & Duration \\
\hline \multirow{2}{*}{ DandaKoNak } & $\begin{array}{l}\text { 5:00 am } \\
\text { to 9:00 } \\
\text { am }\end{array}$ & 4 hrs \\
\cline { 3 - 4 } & day & $\begin{array}{l}\text { 4:00 pm } \\
\text { to 8:00 } \\
\text { pm }\end{array}$ & 4hrs \\
\hline
\end{tabular}

Source: Lekhnath Small Town Water Supply \& Sanitation Users Committee

As per the table, water is supplied 2 times in a day, morning and evening for 4 hours each time. About 54 percent of respondents said that water was available in the tap in a day for 4-8 hours and more than 42 percent said 1-4 hours. More than 70 percent of respondent said that water supplied usually two times in a day. Likewise, about 17 percent of respondents were said that water was supplied only one time in a day. This reveals that high level of service in hours and timing was not maintained.

Table 4.3 indicates that most of the respondents were satisfied with the hours and timing of water supply. 46 percent of the respondents were satisfied while about 36 percent were neutral. The satisfaction scale of satisfaction with hours and timings of water supply is 3.45 (Table 4.4). This is shown in figure below.

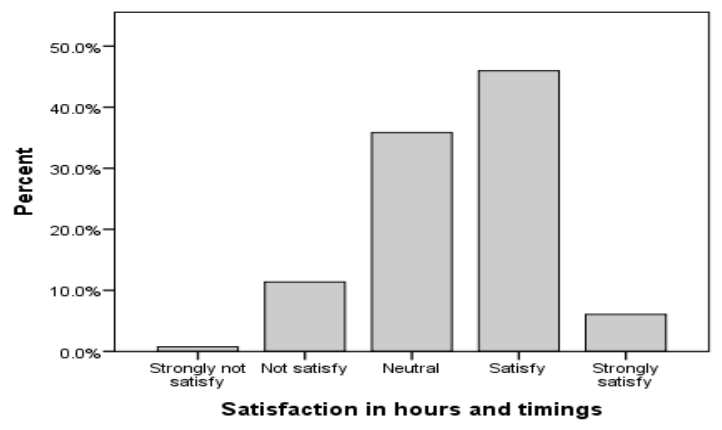

Fig. 4.1 Percent of Satisfaction with Hours \& Timing

\subsubsection{Satisfaction with Quantity of Water Supplied}

The quantity of water delivered and used for households is an important aspect of domestic water supplies. Quantity of water supplied is major parameters for user's satisfaction in water supply project. The water quantity available was difficult to estimate as the visit and was taken by the respondents' opinion. The main uses 
of water in households are drinking, cooking, washing \& bathing, kitchen garden \& cleaning including personal hygiene and other activities. The average household use of water in Danda Ko Nak distribution system was approximately 450 liter/day (LSTWSS). Only about 15 percent of respondent said that the supplied water was enough for their domestic purpose. Likewise, more than 67 percent of respondent said that water supplied was sometimes enough and sometimes not enough and more than 11 percent of respondent said that water supplied was not enough for their domestic purpose. Most of the respondents were satisfied with the quantity of water being supplied. About 42 percent of respondents were satisfied while more than 37 percent were neither satisfied nor dissatisfied they were neutral (Fig. 4.2). This reveals that high level of service in water quantity was not maintained.

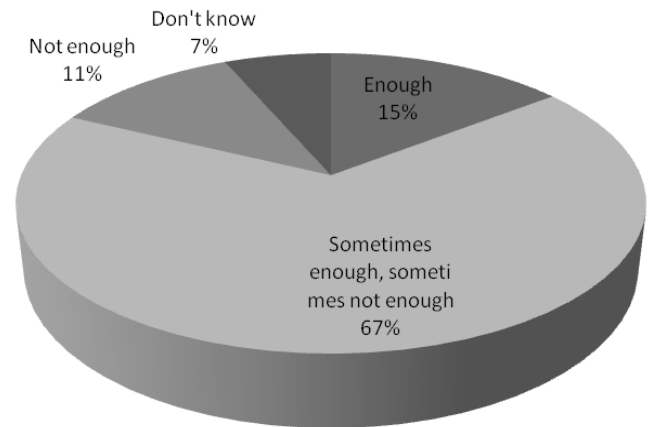

Fig. 4.2 Response of Users about Quantity of Water

Table 4.3 indicates that most of the respondents were satisfied with the quantity of water being supplied. About 42 percent of respondents were satisfied while more than 37 percent were neither satisfied nor dissatisfied they were neutral. The satisfaction scale of satisfaction with quantity of water supplied is 3.43 (Table 4.4).

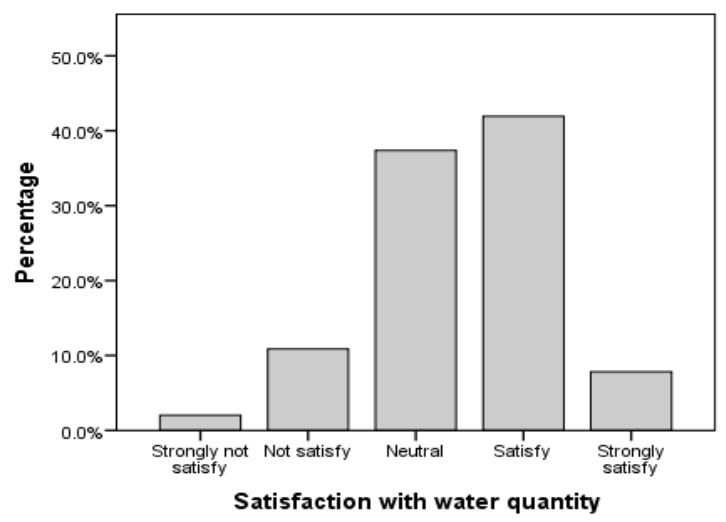

Fig. 4.3 Percentage of Satisfaction with Water Quantity

\subsubsection{Satisfaction with Tap Pressure}

Tap pressure makes a flow of water strong or weak. Water pressures vary in different locations of a distribution system but it effectively contributes to users' satisfaction in water supply system. Table 4.6 shows the water pressure on tap near Shishuwa, Begnas, Bhandardhik, Gagangauda \& Majhuwa respectively at the users' tap.

Table 4.6: Tap Pressure

\begin{tabular}{|c|c|c|c|}
\hline $\begin{array}{c}\text { Sample } \\
\text { Tap }\end{array}$ & $\begin{array}{c}\text { Bucket } \\
\text { Size } \\
\text { (Liter) }\end{array}$ & $\begin{array}{c}\text { Duration } \\
\text { to Fill } \\
\text { (Sec) }\end{array}$ & $\begin{array}{c}\text { Tap } \\
\text { Pressure } \\
\text { (liter/ } \\
\text { sec) }\end{array}$ \\
\hline Tap 1 & 4.5 & 18 & 0.25 \\
\hline Tap 2 & 5.0 & 24 & 0.20 \\
\hline Tap 3 & 5.0 & 19 & 0.26 \\
\hline Tap 4 & 4.0 & 16 & 0.25 \\
\hline Tap 5 & 2.5 & 10 & 0.25 \\
\hline
\end{tabular}

Source: Field Observation

Examination of Table 4.3 indicates that majority of the users were also satisfied with the tap pressure. More than 44 percent of the respondent users were satisfied and about 
41 percent users were neutral, they were neither satisfied nor dissatisfied. The scale of satisfaction of satisfaction with tap pressure is 3.33 (Table 4.4) where 1 indicates strongly not satisfied and 5 indicates strongly satisfied.

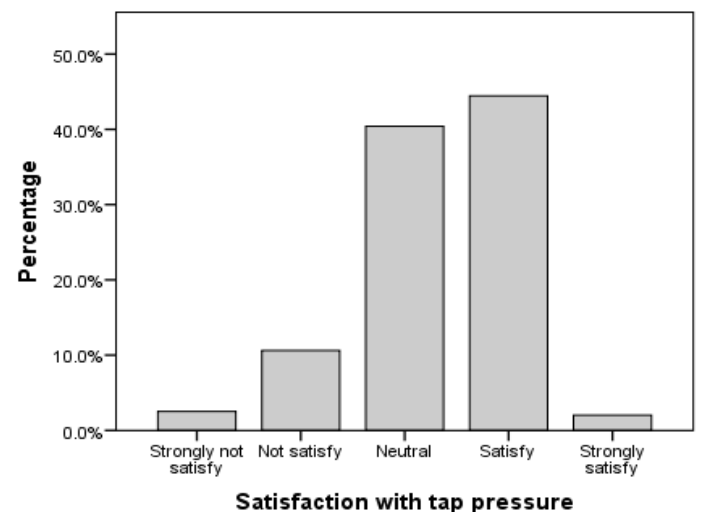

Fig. 4.4 Percentage of Satisfaction with Tap

Pressure

\subsubsection{Satisfaction with Quality of Water}

One of the most important aspects for satisfaction regarding water supply is the satisfaction with the quality of water that is being supplied. Table 4.7 shows the water quality on tap near Shishuwa, Begnas, Bhandardhik, Gagangauda \& Majhuwa respectively at the users' tap.

Table 4.7: Water Quality Test Value

\begin{tabular}{|l|c|c|c|c|c|}
\hline $\begin{array}{l}\text { Water Quality } \\
\text { Parameters }\end{array}$ & S1 & S2 & S3 & S4 & S5 \\
\hline Temperature & 18 & 19.5 & 19 & 18.5 & 19 \\
\hline PH & 8.1 & 8.2 & 8.1 & 8.0 & 7.9 \\
\hline $\begin{array}{l}\text { Electrical } \\
\text { conductivity }\end{array}$ & 179 & 190 & 188 & 180 & 178 \\
\hline Turbidity & $<5$ & $<5$ & $<5$ & $<5$ & $<5$ \\
\hline Taste/Odor & Not objectionable taste \& odor \\
\hline Total coliform & 0 & 0 & 0 & 0 & 0 \\
\hline E. coli & 0 & 0 & 0 & 0 & 0 \\
\hline
\end{tabular}

Source: Lab test report

Biological parameter: Water supplied to the community from Danda Ko Nak distribution system should not to be contaminated with E. coli and total coli forms. The absence of E. coli clearly indicates that the supplied water is free of fecal contamination in this distribution system. The water supplied to community from this distribution system was found safe and good quality as it meets both WHO guidelines and National drinking water quality standards (2062 BS).

The table 4.7 above shows that the PH values of sampled water was nearly 8.0. The National Drinking Water Quality Standards requires $\mathrm{PH}$ to be between 6.5 and 8.5 (Government of Nepal 2002). The National Drinking Water Quality Standard and the WHO guideline for EC, Turbidity, are 1500, 5 to 10 respectively. All of the parameters tested for five samples were found meeting the quality suggested by National Drinking Water Quality Standard and WHO standard. Thus the final water quality parameter at users' tap meets the National Drinking Water Quality standard and WHO guidelines. This indicates that high level of service in water quality was not maintained.

Among the respondents, 35 percent said that the quality of water supplied was good while 50 percent of respondents said that water was medium and about 7 percent of respondents said that the quality of water supplied in their tap was very good. More than 43 percent of the respondents were neutral with the quality of water supplied, while more than 42 percent of the respondents were satisfied with quality of water supply. 


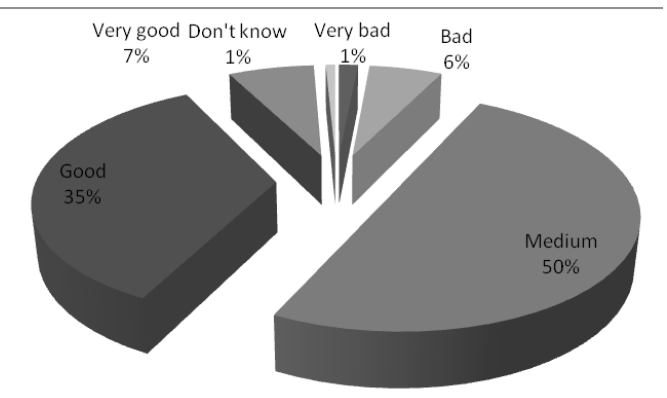

Fig. 4.5 Response of Users about Quality of Water

Table 4.3 indicates that more than 43 percent of the respondents were neutral with the quality of water supplied, while more than 42 percent of the respondents were satisfied with quality of water supply. The satisfaction scale of satisfaction with quality of water is 3.39 (Table 4.4).

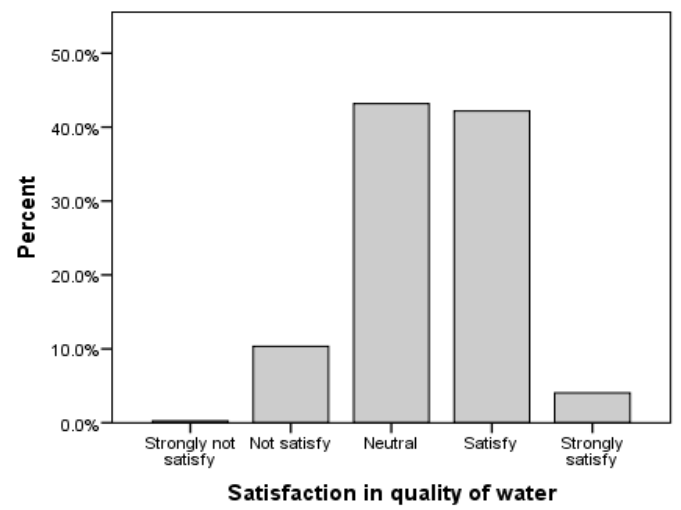

Fig. 4.6 Percentage of Satisfaction with Quality of Water

4.2.5 Satisfaction with Responsiveness and Communication of Management

With regard to complaints redress and communication with users, the WUSC recorded 142 complaints from users and 98 nos. of major and minor pipe leaks were repaired. Consumers can complain at the water utility office or directly to the technical persons (Lekhnath small town water supply \& sanitation users' committee). About 57 percent respondents said Volume 2 Issue 1 that there was a provision for the complaint regarding any problem with water supply and they get the message before or during the regular or emergency maintenance in pipe line through media.

As per the table 4.3, about 44 percent respondents were neutral and about 37 percent respondents were satisfied. The satisfaction scale of satisfaction with responsiveness and communication of management is 3.27 (Table 4.4).

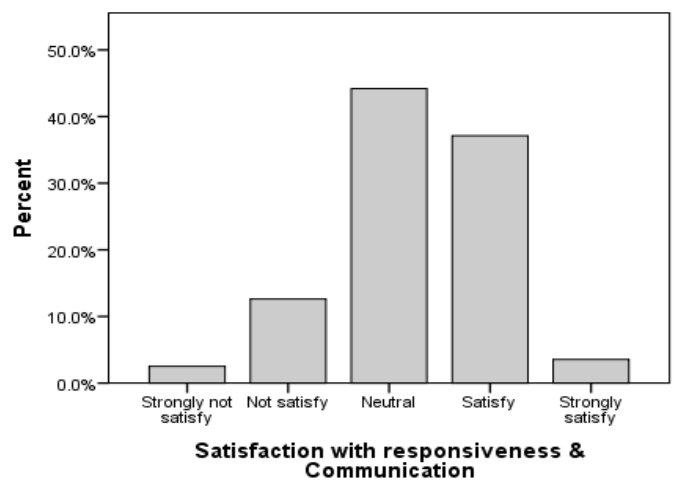

Fig. 4.7 Percentage of Satisfaction with Responsiveness \&Communication

\subsubsection{Satisfaction with Water Tariff}

Rate of water tariff also has its influence on satisfaction with water supply project. The willingness to pay is dependent on the level of satisfaction of users. Among the respondents 29 percent paid the water tariff less than Rs. 200 per month while 51 percent of respondents paid Rs. 201 to Rs. 500. About 93 percent of respondents paid water tariff monthly.

Table 4.3 indicates that majority of the users were satisfied with the water tariff. More than 38 percent of the respondent users were satisfied and about 37 percent users were neutral, they were neither satisfied nor dissatisfied. The scale of satisfaction of satisfaction with water tariff is 3.27 Table 4.4) when 1 indicates strongly not 
satisfied and 5 indicates strongly satisfied.

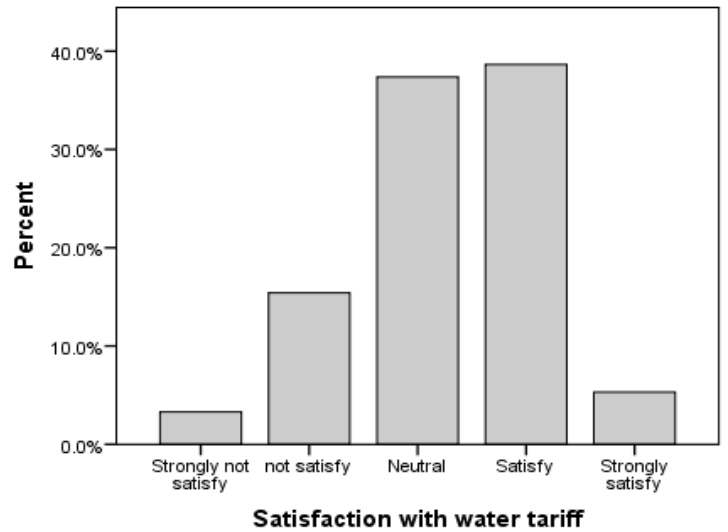

Fig. 4.8 Percentage of Satisfaction with Water Tariff

\subsubsection{Overall Level of Satisfaction with Water}

\section{Supply Services}

The higher level of satisfaction with water supply is expected to be positively related to several factors such as satisfaction with water quality, and other parameters such as hours \& timings of water supply, tap pressure, quantity of water supplied, responsiveness \& communication of management and water tariff. The respondents level of satisfaction (Table 4.3) indicates that about 41 percent of respondents were neutral, they were neither satisfied nor dissatisfied with water services, while about 36 percent of respondents were satisfied with water services. The satisfaction scale of overall satisfaction with water services was 3.29 (Table 4.4) while 1.0 indicates strongly not satisfied while 5.0 indicates strongly satisfied. The various aspects that influence satisfaction among users which include hours \& timings of water supply, tap pressure, quantity of water supplied, responsiveness \& communication of management and water tariff as well as redresses of customer complaints have been examined above.

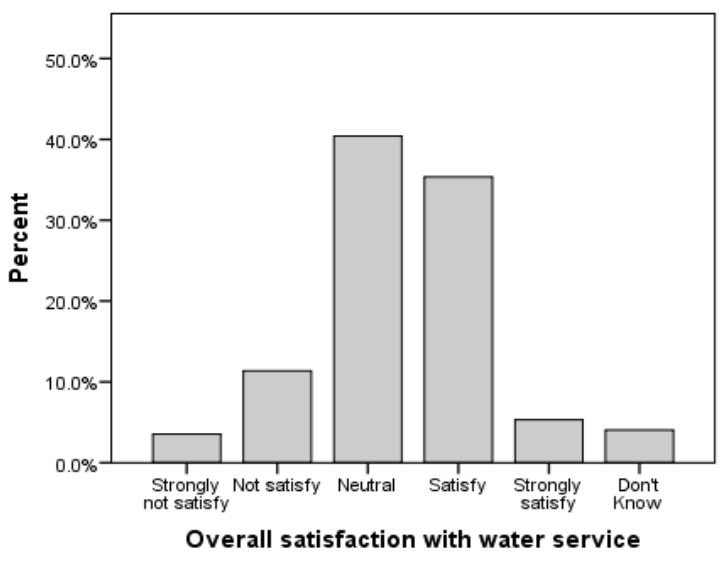

Fig. 4.9 Percentage of Satisfaction with Overall Water Services

\section{Conclusions}

People have always strived to develop and to achieve better results and improvements. Today, organizations and companies are facing new challenges and experiencing pressure to improve. Furthermore, the customers' expectations are changing and thus customer focus and level of satisfaction have become a driving force for many companies and organizations. By measuring the degree of satisfaction, an organization can determine if they have in fact improved and if their improvements have resulted in desired effects. Moreover, the very act of surveying sends a message that you care about your customers and their needs and views. The purpose of the thesis and this study was to evaluate the users' satisfaction of Lekhnath small town water supply and sanitation project. More and more companies and organizations are using the level of customer satisfaction as an indicator on their performance of delivered products and services. Among the respondents, about 41 percent of respondents were neutral; they were neither satisfied nor dissatisfied with water services, while about 36 percent of respondents' were 
satisfied with water services. The satisfaction scale of overall satisfaction with water services was 3.28.

This study focus on the users' satisfaction of Lekhnath small town water supply and sanitation project and the study was undertaken to analyze the current users' satisfaction of the Lekhnath small town water supply and sanitation project. The result shows that the satisfaction level of users' is above neutral but they are not in satisfying level. The characteristics/aspects of the service that contributed to users' satisfaction include hours and timing, pressure, quantity and quality of water while there was slightly less satisfaction with regard to complaints about water supply.

\section{References}

Abrams, L.J. (1998) Understanding Sustainability of Local Water Services. As cited in Carter, R., Tyrrel, S., Howsam, P. (1999) Impact and Sustainability of Community Water Supply and Sanitation Programmes in developing Countries. Journal of the Chartered Institution of Water and Environment Management. Vol 13 NO 4 PP 292-296.

ADB (2013). Solid Waste Management

in Nepal. Current Status and policy Recommendations. Retrieved from: http:// www.iplaportal.org/upload/document/135/ solid-waste-management-nepalADBAug2013.pdf

APHA, AWWA and WEF (2012), Standard Methods for the Examination of Waterand Wastewater. 22 ${ }^{\text {nd }}$ Edition.American Public Health and Association, AmericanWater Works Association, and Water Environment Federation, Washington DC. Arkin, H. \& Colton, R. (1963). Tables for
Statisticians. New York: Barnes \& Noble.

Asthana, A. (1997). Where the water is free but the buckets are empty: demand analysis of drinking water in rural India. Open Economies Review 8(2):137-149.

Barnes, R. \&Ashbolt, N. (2010). Development of a Planning Framework for Sustainable Rural Water Supply and Sanitation: A Case Study of a Filipino NGO. International Studies of Management \& Organization, (40)3, 78-98.

Bhandari, B. \& M. Grant (2007). “User Satisfaction and Sustainability of Drinking Water Schemes in Rural Communities of Nepal". Spring Vol.3: 12-20.

Bohm, R., Essenburg, T., \& Fox, W. (1993). Sustainability of potable water services in the Philippines. Water Resources Research 29(7):1955-1963.

Brikké, Francois and Rojas, Johnny (November 2001) Key-factors for sustainable cost recovery: in the context of communitymanaged water supply. IRC International Water and Sanitation Centre.

Brikke, Francois (2002) Operation and maintenance of rural water supply and sanitation systems: A training package for managers and planners. In Cardone, Rachel and Fonseca, Catarina (2003) Financing and Cost Recovery. IRC International Water and Sanitation Centre. Carter, R. C., Tyrell, S. F. \&Howsam, P. (1999). The Impact and Sustainability of Community Water Supply and Sanitation Programmes in Developing Countries. Water and Environment Journal, 13(4), 292-296.

Doria M.D.F (2010). Factors influencing public perception of drinking water quality. Water policy 12:1-19. 
Nepal Engineers' Association, Gandaki

Francisco OsnyEneas da Silva, Tanya Heikkila,

Francisco de Assis de Souza Filho and

Daniele Costa da Silva (2013). Developing

Sustainable and Replicable Water Supply

System in Rural Communities in Brazil. In

Press at The International journal of Water

Resources Development.

WHO. (2004a). Guidelines for Drinking-water

Quality. World Health Organization,

Geneva.

WHO (2009) '10 facts about water scarcity'.

Retrieved from http://www.who.int/features/

factfiles/water/water facts/en/index 3. html

WHO/UNICEF (2006). "Core Questions

on Drinking-water and Sanitation for

Household Surveys."WHO Library

Cataloguing-in-Publication Data.
Wilkinson, S. (1997). Focus group research. In Silverman, D. (ed.) Qualitativeresearch: Theory, method and practice, pp. 177-199. London: Sage Publications.

World Bank Water Demand Research Team. (1993). The demand for water in rural areas: determinants and policy implications. The World bank Research Observer 8(1):47-70.

WSSCC, 2010, Global Sanitation Fund: Investing in sustainable sanitation and hygiene. Geneva: Water Supply and Sanitation Collaborative Council. 